\title{
Effects of urban infrastructure on aquatic invertebrate diversity
}

\author{
Mia Vehkaoja ${ }^{1}$ (D) $\cdot$ Milla Niemi ${ }^{2} \cdot$ Veli-Matti Väänänen ${ }^{1}$
}

Published online: 3 March 2020

(C) The Author(s) 2020

\begin{abstract}
Wetlands are one of the world's most important, economically valuable, and diverse ecosystems. A major proportion of wetland biodiversity is composed of aquatic invertebrates, which are essential for secondary production in aquatic and terrestrial food webs. Urban areas have intensified the challenges wetlands encounter by increasing the area of impermeable surfaces and the levels of nutrient and pollutant overflows. We investigated how urban infrastructure affects the aquatic invertebrate fauna of urban wetlands in metropolitan Helsinki, southern Finland. We measured riparian canopy cover, emergent vegetation coverage, and various land cover and road variables. Recreation area, forests, and open natural areas were the most important landscape features positively influencing aquatic invertebrate family richness, whereas buildings and roads had a negative effect on family richness and abundances of many taxa. Recreation area and the various forest types also positively affected the $\alpha$-diversity indices of wetlands. On the other hand, fish assemblage did not affect either family richness or abundances of the studied taxa. Furthermore, trees growing on the shoreline negatively affected the diversity of aquatic invertebrate families. Invertebrate family diversity was greatest at well-connected wetlands, as these areas added to the regional species pool by over 33\%. Our results show that connectivity and green areas near wetlands increase aquatic invertebrate family diversity, and our results could be utilized in urban planning.
\end{abstract}

Keywords urban landscape $\cdot$ urban planning $\cdot$ wetlands $\cdot$ wetland biodiversity $\cdot$ urban wetlands $\cdot$ stormwater wetlands

\section{Introduction}

Wetlands are one of the world's most important and valuable ecosystems (Emerton and Bos 2004; Finlayson and D'Cruz 2005; Takamura 2012; Russi et al. 2013; Costanza et al. 2014; Oertli and Parris 2019). Their value is mostly based on the ecosystem services they produce (Woodward and Wui 2001; MEA 2005) and the thousands of species they inhabit (The Pond Manifesto EPCN 2008). Water purification is one of the key ecosystem services wetlands produce (Oertli and Parris 2019). They maintain environmental water balance by upholding water through drought periods and reciprocally by mitigating flooding during heavy rain episodes (Takamura 2012). Wetlands are rightly referred to as the Earth's kidneys.

Mia Vehkaoja

mia.vehkaoja@helsinki.fi

1 Department of Forest Sciences, University of Helsinki, P.O.Box 27, 00014 Helsinki, Finland

2 Metsähallitus, Wildlife Service Finland, Pohjoispuisto 7, 28100 Pori, Finland
Despite their importance and value, the world has lost approximately half of its wetlands during the past century (Amezaga et al. 2002; Davidson 2014). Furthermore, the disappearance rate of wetlands has progressively increased since the 18 th century and is nowadays three times faster than the forest disappearance rate (Davidson 2014). Human population growth, habitat destruction, draining, and urbanization are some of the main reasons behind this loss (Vörösmarty et al. 2010). In addition to destruction, the remaining wetlands have confronted alteration and landscape changes (Oertli and Parris 2019). However, the main causes affecting wetlands are anthropogenic (Dudgeon et al. 2006; Vörösmarty et al. 2010; Clark et al. 2014).

Urban areas inhabit nearly four billion people worldwide (Schneider et al. 2010; Solecki et al. 2013), and almost 75\% of Europeans live in urban areas (European Union 2016). On the other hand, urban areas cover approximately just one percent of the Earth's surface (Schneider et al. 2010; Solecki et al. 2013). Yet, urban area cover is increasing much faster than the human population in urban areas, and this increase is expected to continue in the future (Angel et al. 2011; Seto et al. 2011). This trend can be seen worldwide, but especially in China, Mexico, and Turkey (Seto et al. 2012). Because urban 
areas are very populous and tightly built, nature is pushed into a corner. Furthermore, buildings and roads sever the connections between the remaining patches of nature (McDonald et al. 2008; McKinney 2008). Roads, as impermeable surfaces, do not filter water or nutrients and pollutants into the ground, but rather increase run-offs and nutrients and pollution accumulation (Paul and Meyer 2001). On the other hand, traffic increases the mortality of both invertebrates (Seibert and Conover 1991) and vertebrates (Dhindsa et al. 1988; Trombulak and Frissell 2000). Buildings also create barriers, which affect the dispersal of many animals, including flying animals.

Urban wetlands are mostly man-made such as garden ponds and stormwater wetlands. Nevertheless, they offer habitats for many organisms (Hassall 2014). Garden ponds are small and rapidly colonized by amphibians and invertebrates (Gaston et al. 2005; Davies et al. 2009; Hill and Wood 2014). Stormwater wetlands, on the other hand, are built for human purpose but concurrently provide a suitable habitat for many invertebrates (Hassall and Anderson 2015). Previous studies have showed that stormwater wetlands can inhabit nearly as diverse biodiversity as natural wetlands outside cities (Hassall and Anderson 2015). Connectivity loss is one of the main problems that urban wetlands suffer from(Oertli et al. 2002; Gledhill et al. 2008; Martinez-Sanz et al. 2012; Hill et al. 2018). Urban infrastructure creates barriers for organisms and hampers the dispersal of animals (Oertli and Parris 2019). The loss of connectivity between wetlands is known to have a much more pronounced effect on regional diversity than direct habitat loss would be expected to (Amezaga et al. 2002). Connectivity loss is often emphasized in aquatic communities, in which the ability to disperse varies greatly (Keddy 2000; Colburn 2008; Heino et al. 2017).

Aquatic invertebrates are an essential group in wetland ecosystems (Wissinger 1999). They comprise the main biomass of wetland food webs (Wissinger 1999) and are considered a key group of freshwater ecosystems (Covich et al. 1999; Moore and Palmer 2005). Their importance is based on their numbers and diversity (Hassall 2014), in addition to their role in secondary production in both aquatic and terrestrial food webs (Covich et al. 1999; Euliss et al. 1999; Davies et al. 2016; Stewart et al. 2017). Aquatic invertebrates function as both prey and predators (Hassall 2014), and they take an active part in cycling nutrients and organic matter (Brönmark et al. 1992; Martin et al. 1992; Jones and Sayer 2003).

Wetlands, including urban wetlands, have reached increasing interest and many studies have been conducted on urban wetlands (Dudgeon et al. 2006; Takamura 2012; Hassall et al. 2016; Hill et al. 2016). Most of these studies have focused on how urban infrastructure affects the water chemistry of urban wetlands and the aquatic invertebrate community as a result of this (Wood et al. 2001; Gledhill et al. 2008; Foltz and Dodson 2009; Apinda Legnouo et al. 2013; Fontanarrosa et al. 2013;
Hill et al. 2015). In our study, we focus on how the amount of various urban infrastructures (e.g. various building and road types) around urban wetlands influences aquatic invertebrate community assemblage and size. In addition, our study concentrates mostly on naturally occurring urban wetlands. We hypothesize that roads and buildings near wetlands decrease aquatic invertebrate richness. Secondly, we assume that the greatest richness will be found in urban wetlands that are well connected to other wetlands.

\section{Materials and methods}

\section{Study sites}

Our study was conducted in metropolitan Helsinki $\left(60^{\circ} 13^{\prime} \mathrm{N}\right.$, $24^{\circ} 51^{\prime} \mathrm{E}$ ), which is located in southern Finland and is composed of three cities: Espoo, Helsinki, and Vantaa (Fig. 1). The total area is $669 \mathrm{~km}^{2}$. Metropolitan Helsinki has approximately 1.16 million citizens and it is the most populous urban area in Finland. The area belongs to the southern boreal vegetation zone, and over $30 \%$ of the area is covered in forests, which are predominantly coniferous with deciduous patches scattered around the landscape. Most of the forests are located in two national parks (Nuuksio and Sipoonkorpi) that occur in the metropolitan Helsinki area. We excluded these two national parks from our study area, to be able to solely focus on the urban areas.

Metropolitan Helsinki is located by the Baltic Sea, with more than $100 \mathrm{~km}$ of coastline. Glacial and sandy tills are the dominant soil types and soils are consequently low in nutrients. The annual average precipitation is approximately $700 \mathrm{~mm}$ and the thermal growing season is $175-185$ days.

First, we located all the wetlands in our study area using maps and satellite images. We found 152 wetlands and randomly chose 50 of them for our study (Appendix Table 3). Randomization of study wetlands was performed in the $\mathrm{R}$ program using the randomizeR package. Our wetlands included both permanent $(\mathrm{N}=40)$ and temporary wetlands $(\mathrm{N}=10)$. The permanent wetlands also included 10 stormwater wetlands.

\section{Sampling}

We selected spring (post-snowmelt) for our sampling season, because most macroinvertebrates are still in their larval stages at that time (Heino 2014), which increases the likelihood of capture. We collected the invertebrates between April 30 and May 19, 2018. Each wetland site was sampled for $48 \mathrm{~h}$ in 12-h timeframes to avoid premature death of the animals. We even spaced 10 activity traps at each site. We used 1-l glass jars and transparent plastic funnels with 120 -mm openings at the wide end and 20-mm openings at the narrow end (see e.g., Elmberg 


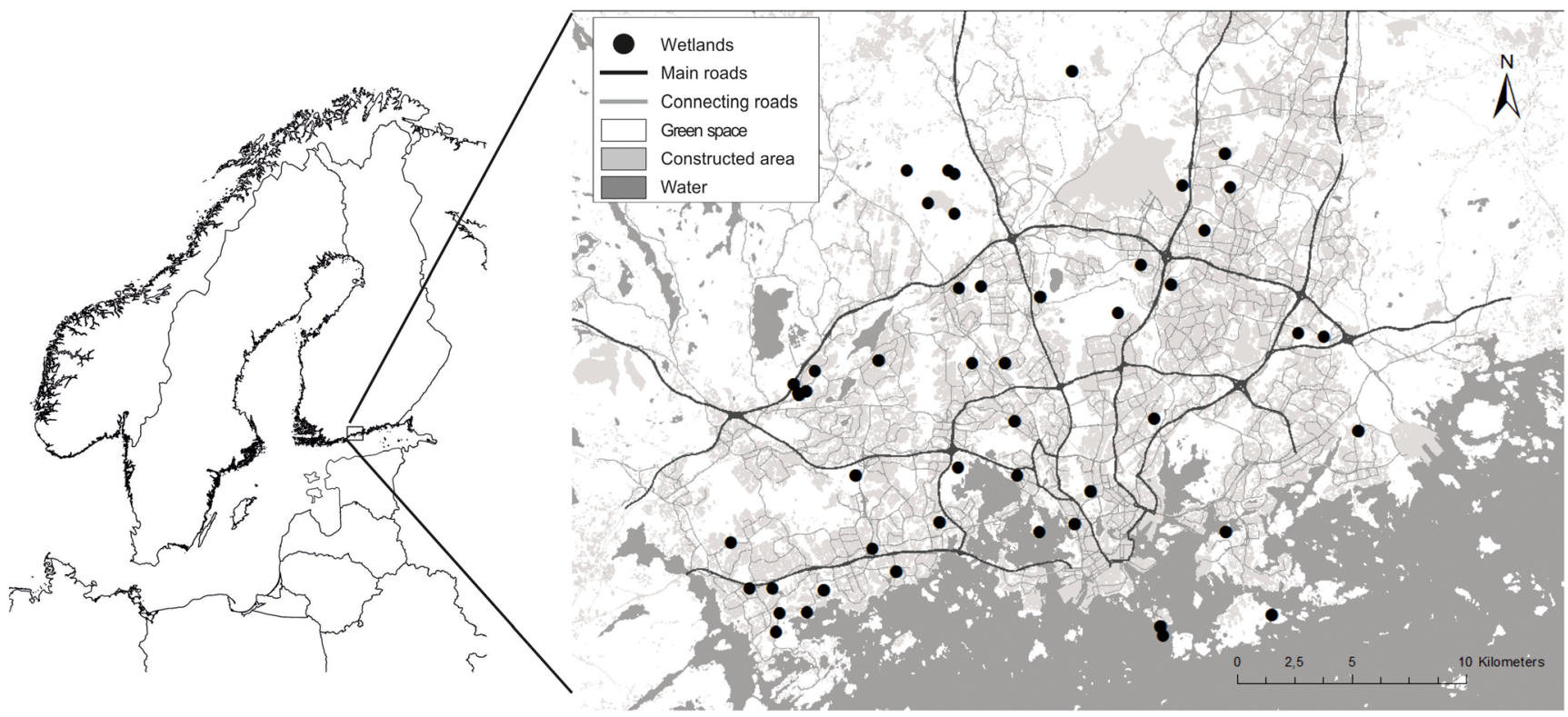

Fig. 1 Map of the study area, metropolitan Helsinki.

et al. 1992). The activity traps were placed at a depth of approximately one meter. We identified and calculated all invertebrate families in the field. The trapped individuals were poured through a strainer, identified, calculated, and then released back into the wetland. This method gives an abundance index and is used especially for nektonic and benthic invertebrates (Becerra Jurado et al. 2008). We chose to identify the animals to family level, because we wanted to focus more on community structures rather than specific species.

\section{Environmental and land cover variables}

Riparian canopy cover and submerged and emergent vegetation coverage were environmental variables measured for all the study sites. The average coverage of four randomly defined squares $\left(1 \mathrm{~m}^{2}\right.$ each) were calculated for each study site to determine its emergent vegetation coverage. We photographed the canopy cover using a Canon EOS 550d with a focal length of $25 \mathrm{~mm}$. Canopy cover was photographed by perpendicularly facing the sky while standing on the shoreline. The photographs were divided into 3700 small squares per picture using Canon Digital Photo Professional. The proportion of squares with canopy coverage was calculated from these squares. We calculated average canopy coverage for each study site from four photograph stations set up at each site. These were located in the same places as the vegetation squares.

The land cover data included coverage of residential buildings, industrial and service buildings, other buildings, recreation area, farming area, deciduous, coniferous and mixed forests, other open natural areas, wetlands, and water systems (mainly sea area). The road data comprised main roads, connecting roads, streets, walkways, and all road and street types together. We calculated the land cover and road data from a one-km radius circle around the study sites. The data were extracted from the Finnish national version of the CORINE Land Cover 2012 database, where land use in Finland is presented with a pixel size of 20 m* 20 m (Finnish Environment Institute 2014). Road data were extracted from the national database of the Finnish road and street network, Digiroad (Finnish Traffic Agency 2018). We processed the landscape and road data using ArcMap 10.3.1 (ESRI 2015).

\section{Principal component analysis (PCA)}

In addition to the 18 environmental variables, we also analyzed the variables using principal component analysis (PCA, see e.g., Pimental 1979; Gauch 1982) to explore the main environmental factors defining the study sites. The first and second PCA components explained $29.1 \%$ and $17.6 \%$ of the total variation in the habitat data, so these two components combined explained $46.7 \%$ of the variation. The score values of the first component organized the wetlands onto an isolation gradient: habitats with various types of forests and recreation areas nearby, rich emergent vegetation, and location next to other wetlands were situated at the positive end of the gradient, while habitats with roads and various building types were at the negative end. All 50 wetlands were categorized according to their isolation scores received from the PCA. Wetlands with an isolation score between -3 and -0.5 were categorized as isolated. Wetlands that scored between -0.5 and 0.5 were categorized as partly connected, and wetlands with a score of over 0.5 were categorized as well connected. 


\section{Data analyses}

Aquatic invertebrate richness was calculated for each site $(\mathrm{n}=$ 50 ). We analyzed the number and abundance of aquatic invertebrate families by comparing the data between environmental and land cover variables along with the isolation score received from the PCA. Both family richness and the abundance of invertebrate families were count data with a Poisson distribution (log). Family richness data meet the assumptions of the Poisson regression model, so we analyzed them using generalized linear modeling with the glm function (Bolker et al. 2009; Zuur et al. 2009) fit by maximum likelihood with the glmer function in the lme4 library (Bates and Maechler 2009) in R 3.0.2 (R Development Core team 2013).

The abundance data were overdispersed due to the many zeros in the data. However, we did not want to drop any of the observations. For this overdispersed data, we used negative binomial modeling with the glm.nb function, which solved our overdispersion problem. We used the mgcv (Wood 2004) and MASS (Venables and Ripley 2002) packages from the software package R (R Development Core team 2013). The explanatory parameters were continuous parameters.

The model selection for family richness and abundances was made by dropping out explanatory variables one at a time until all remaining variables had at least a $95 \%$ significance level (Zuur et al. 93).

\section{Diversity indices}

We used the Shannon-Wiener diversity index because it accounts for both abundance and evenness of the families present. The Shannon-Wiener diversity index is

$\mathrm{H}=\sum\left[\left(\mathrm{p}_{\mathrm{i}}\right) * \ln \left(\mathrm{p}_{\mathrm{i}}\right)\right]$,

where pi is the proportion of the total sample represented by family $i$.

We also examined the similarity of aquatic invertebrate communities between wetland isolation types (well connected, partially connected, and isolated) received from the PCA according to the Jaccard index of similarity. Jaccard's index of similarity is

$\mathrm{SJ}=\mathrm{c} /(\mathrm{a}+\mathrm{b}+\mathrm{c})$,

where $\mathrm{a}$ is the number of unique families in habitat type $\mathrm{A}, \mathrm{b}$ is the number of unique families in habitat type $\mathrm{B}$, and $\mathrm{c}$ is the number of families shared by both habitat types. The Jaccard index makes a comparison of samples based on the presence or absence of families. We selected this similarity index to emphasize family composition and because it does not dilute the importance of rare families. Next, we estimated the dissimilarity between the sites as 1 - SJ. In a broad sense, dissimilarity can be considered turnover (Koleff et al. 2003), and it produces an estimate of the sum of the families unique to either habitat type divided by the regional pool (Gaston et al. 2001; Sabo and Soykan 2006).

$1-\mathrm{SJ}=(\mathrm{a}+\mathrm{b}) /(\mathrm{a}+\mathrm{b}+\mathrm{c})$.

We estimated the proportion of unique families in each wetland isolation type (well connected, partially connected, and isolated) using the formula created by Sabo and Soykan (2006)

$\alpha \mathrm{X}, \mathrm{u}=\mathrm{a} /(\mathrm{a}+\mathrm{b}+\mathrm{c})$.

Additionally, we estimated the proportional increase in the regional family pool due to $\mathrm{X}$ wetland isolation types as

$\gamma \mathrm{X}=\mathrm{a} /(\mathrm{b}+\mathrm{c})$.

\section{Results}

We recorded a total of 9015 individuals from the study sites, belonging to 24 aquatic invertebrate families. The $\gamma$-diversity for the whole study area was 2.37. Four families/subfamilies (Gerridae, Nepinae, Ostracoda, Ranatrinae) were recorded from only one site and no single family was found from all the study sites. Dytiscidae (44 sites), Corixidae (34 sites), Asellidae (28 sites), and Culicidae (28 sites) were the most commonly encountered aquatic invertebrate families.

The most important landscape features related to aquatic invertebrate richness were recreation area (positive effect, from now on "pos"), deciduous forests (pos), mixed forests (pos), industrial and service buildings (negative effect, from now on "neg"), main roads (neg), connecting roads (neg), and tree cover at the shoreline (neg). Recreation area and the different forest types also had a positive effect on the $\alpha$-diversity indices of wetlands. Whereas, fish assemblage did not affect either the species richness or abundance of the studied taxa.

The model that took into account tree cover at the shoreline (neg), recreation area (pos), and open natural areas (pos) was the best model for explaining Corixidae occurrence, whereas the best model for Notonectidae was a model with tree cover at the shoreline (neg), the amount of all road types (neg), and the number of water systems (mostly the Baltic Sea) (neg). Asellidae abundance was best explained by a model with other buildings (neg) and main roads (neg), while on the other hand, the best model to explain Culicidae abundance took into account industrial and service buildings (neg) in addition to wetlands (pos), water systems (the Baltic Sea) (pos) and connecting roads nearby (pos). Contrary to Culicidae, Ephemeroptera abundance was best explained by a model with wetlands (neg) and connecting 
roads (neg) nearby. The best model to explain Gastropoda abundance took into account the tree cover (neg) and deciduous trees nearby the wetland (pos). The model that explained the best Hirudinae abundance was a model with the Baltic Sea (neg) as the explanatory variable. Odonata abundance was the best explained by a model with coniferous forests (pos) and connecting roads (neg) nearby wetlands.

Twenty-one families were found from both well-connected and partially connected wetlands, whereas 17 families were observed from isolated wetlands. The greatest aquatic invertebrate diversity (13 families) was recorded from one of the well-connected wetlands, while one isolated wetland, which also functions as a stormwater wetland, had no aquatic invertebrates, and only fish were trapped. Well-connected wetlands added more than a third to the regional species pool when compared to isolated wetlands (Table 1).

Species richness was higher in well-connected wetlands when compared to both partially connected and isolated wetlands (Table 2.). Additionally, the $\alpha$ diversity index was significantly higher in wellconnected wetlands compared to isolated wetlands but did not differ between well-connected and partially connected wetlands. Furthermore, Dytiscidae and Odonata abundances differed significantly between wellconnected and isolated wetlands (Fig. 2).

\section{Discussion}

Invertebrate diversity was greatest at well-connected wetlands, and as the degree of isolation increased, the number of invertebrate taxa decreased. The well-connected wetlands support families that did not occur in partially connected or isolated wetlands, which indicates that connectivity enhances greater diversity in aquatic invertebrates. Furthermore, aquatic invertebrates make up a major portion of global wetland biodiversity (Covich et al. 1999; Wissinger 1999; Moore and Palmer 2005), and the diversity level of this group can profoundly affect ecosystem functioning and characteristics, as showed by Thébault and Loreau (2003) and Downing and Leibold (2002). In addition,
Table 2 Differences between well-connected, partially connected, and isolated wetlands in terms of species richness, $\alpha$-diversity, and abundances of Dytiscidae and Odonata. Significant p-values in bold. Value represents the wetland type coefficient, Std. Error denotes standard error, $z$-value the test value, and $p$-value the statistical significance. The value of the intercept is compared to values of the other sites. If this value is negative, it is subtracted from the intercept value and if it is positive, it is added to the intercept value.

\begin{tabular}{lllll}
\hline & Estimate & Std. Error & $\begin{array}{l}\text { Z- } \\
\text { value }\end{array}$ & \\
& & & & \\
\hline Species richness & & & & \\
Well connected (intercept) & 2.120 & 0.100 & 21.203 & $<2 \mathrm{e}-16$ \\
Isolated wetlands & $\mathbf{- 0 . 4 7 6}$ & $\mathbf{0 . 1 4 6}$ & $\mathbf{- 3 . 2 5 8}$ & $\mathbf{0 . 0 0 1}$ \\
Partially connected & $\mathbf{- 0 . 3 1 3}$ & $\mathbf{0 . 1 3 4}$ & $\mathbf{- 2 . 3 4 3}$ & $\mathbf{0 . 0 1 9}$ \\
$\alpha$-diversity & & & & \\
Well connected (intercept) & 1.204 & 0.117 & 10.278 & $1.31 \mathrm{e}-13$ \\
Isolated wetlands & $\mathbf{- 0 . 3 6 5}$ & $\mathbf{0 . 1 5 3}$ & $\mathbf{- 2 . 3 8 4}$ & $\mathbf{0 . 0 2 1}$ \\
Partially connected & -0.073 & 0.147 & -0.499 & 0.620 \\
Dytiscidae & & & & \\
Well connected (intercept) & 3.761 & 0.368 & 10.209 & $<2 \mathrm{e}-16$ \\
Isolated wetlands & $\mathbf{- 0 . 9 9 6}$ & $\mathbf{0 . 4 8 4}$ & $\mathbf{- 2 . 0 5 9}$ & $\mathbf{0 . 0 3 9}$ \\
Partially connected & -0.290 & 0.462 & -0.626 & 0.531 \\
Odonata & & & & \\
Well connected (intercept) & 2.464 & 0.766 & 3.217 & 0.001 \\
Isolated wetlands & $\mathbf{- 3 . 5 0 5}$ & $\mathbf{1 . 0 7 8}$ & $\mathbf{- 3 . 2 5 1}$ & $\mathbf{0 . 0 0 1}$ \\
Partially connected & -1.658 & 0.969 & -1.711 & 0.087 \\
\hline
\end{tabular}

the more diverse an animal community is, the more biomass it accumulates (Schneider et al. 2016), which can strongly alter interaction networks at trophic levels (Nichols et al. 2016). Invertebrates are the main nutrition for e.g. dragonflies (Merrill and Johnson 1984), fish (Wellborn et al. 1996; Garcia and Mittelbach 2008: McCauley et al. 2008), and ducklings (Sugden 1973; Eriksson 1976), and consequently aquatic invertebrate assemblage and biomass can have a very strong effect on these groups.

We found wetland connectivity to have a differing effect on different aquatic invertebrate families. Buildings and roads near wetlands weaken the connectivity of urban wetlands (Hassall 2014). Again, according to our results, buildings near wetlands proved to have a negative influence on the number of aquatic

Table 1 The Jaccard index of similarity and dissimilarity of invertebrate groups between the wetland types.

\begin{tabular}{llllllllllll}
\hline A & B & a & $\mathrm{b}$ & $\mathrm{c}$ & $\mathrm{Sj}$ & & $1-\mathrm{Sj}$ & $\begin{array}{l}\text { Prop. of unique } \\
\text { species in A }\end{array}$ & $\begin{array}{l}\text { Prop. of unique } \\
\text { species in B }\end{array}$ & $\begin{array}{l}\text { A's increase in } \\
\text { the species pool }\end{array}$ & $\begin{array}{c}\text { B's increase in } \\
\text { the species pool }\end{array}$ \\
\hline Isolated & Partially connected & 0 & 4 & 17 & 0.81 & 0.19 & 0 & 0.19 & 0 & 0.24 \\
Isolated & Well connected & 2 & 6 & 15 & 0.65 & 0.35 & 0.09 & 0.26 & 0.10 & 0.35 \\
Partially connected & Well connected & 3 & 3 & 18 & 0.75 & 0.25 & 0.13 & 0.13 & 0.14 & 0.14
\end{tabular}

$\mathrm{Sj}=$ the Jaccard index of similarity. $1-\mathrm{SJ}=$ the estimate of the dissimilarity. $\mathrm{a}=$ number of unique species groups in wetland type $\mathrm{A}, \mathrm{b}=$ number of unique species groups in wetland type B and $\mathrm{c}=$ number of species groups shared by both wetland types. 

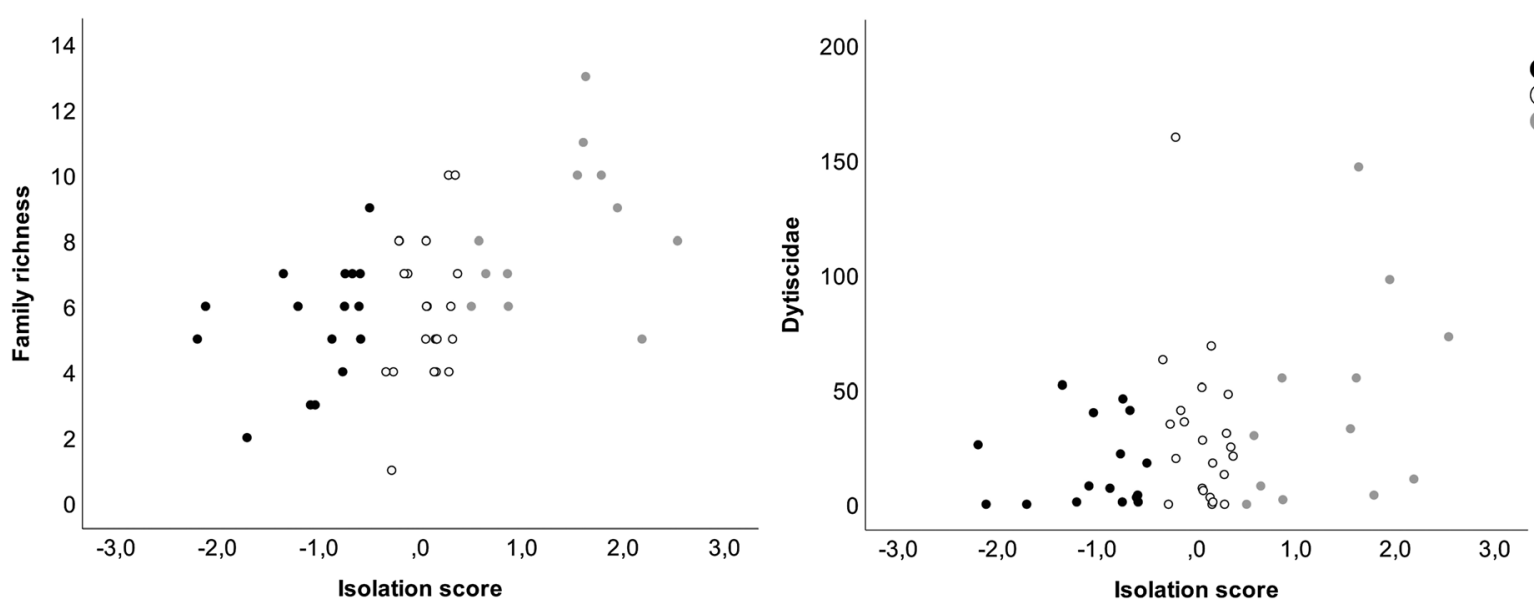

Fig. 2 Species richness and Dytiscidae abundance represented according to isolation score.

invertebrate families, along with on the abundance of Asellidae and Culicidae. On the other hand, roads, especially roads with moderate or high traffic speeds, seem to have an even more profound effect on aquatic invertebrates. Roads significantly negatively affected many of the taxa, except for Dytiscidae, Odonata, Lymnaeidae, Hirudinae, and Culicidae. Dispersal ability (e.g. flight ability), body size, and competence have an influence on the road and building effect (Heino et al. 2017). For example, the flight ability of Culicidae varies between species. Certain species are very poor fliers while some are strong fliers (Verdonschot and Besse-Lototskaya 2014). Moreover, most Culicidae with poor or very poor flight ability prefer urban landscapes (Verdonschot and Besse-Lototskaya 2014), which could explain why at least buildings play a role in Culicidae abundance in the urban wetlands of the Helsinki metropolitan. Interestingly, connecting roads had a positive effect on Culicidae. This may be caused by the large nutrient quantities washed from the roads into the wetlands, which benefit Culicidae larvae.

While roads and buildings hampered the occurrence of diverse aquatic invertebrates, recreation areas and forests near the wetlands appeared to benefit many of the aquatic invertebrate taxa. However, trees growing on the shoreline negatively affected the diversity of aquatic invertebrates. Tree cover blocks sunlight and may decrease the water temperature (Skelly et al. 2002). Warmer water temperature accelerates the development of most of the invertebrate larvae and additionally provides dense aquatic vegetation, which as such create complex habitats and food for versatile species groups (Werner and Glennemeier 1999; Relyea 2002; Skelly et al. 2002; Urban 2004).

Our results could benefit urban landscape planning. Since 2015, Finnish cities have been obligated to process urban runoff (MRL 132/1999, 103 a-o §). As a result, many Finnish cities turned to nature for help, as wetlands are known to retain and process impurities occurring in water (Keddy 2000; Mitch and Gosselink 2007; Takamura 2012; Oertli and Parris 2019). The purpose of stormwater wetlands is, in addition to processing urban runoffs, to mitigate the flow of stormwater and to store snow (Woodward and Wui 2001; Takamura 2012). Tightened legislation has led to the construction of stormwater wetlands in Finland, but also in many other European countries (Hassall 2014; Oertli and Parris 2019). It is positive and essential to realize that in addition to processing urban runoffs, they can maintain as high and versatile a biodiversity level as natural wetlands (Hassal and Anderson 2015). One potential reason behind the species richness of stormwater wetlands may be that at least in Finland, they are usually built near or in the middle of recreational areas. In our study, recreational areas positively affected the number of species groups along with the $\alpha$-diversity index. Urban planning should take into account the positive effects of recreation and forest areas near urban wetlands, and planning officers should leave green spaces near urban wetlands, especially when building new stormwater wetlands. Green spaces left near urban wetlands should be planned so that trees near the shoreline are removed.

After destroying wetlands, we are gradually beginning to recognize their value and working to restore them. In urban areas, this is accomplished by building stormwater wetlands. From a biodiversity aspect, connectivity and the surrounding environment are two of the most influential factors affecting the species pool and community structure of wetland invertebrates. Our current findings support the notion that the loss of connectivity has a very strong effect on wetland biodiversity and community structure. Therefore, our results show a link not only between connectivity and aquatic invertebrate diversity, but also between dispersal barriers (roads and buildings) and a reduction in aquatic invertebrate taxa.

Our findings show that urban wetlands can maintain great aquatic invertebrate diversity. By leaving a considerable amount of forests and meadow habitats around urban wetlands, we can concurrently conserve species with varying habitat requirements. Today conservation aims are more and more focusing on whole ecosystems and landscapes with high biological diversity (Franklin 1993; Hanski 1999; Turner et al. 2003). Additionally, the International Union for Conservation of Nature (IUCN) is moving its conservation focus towards larger scales, rather than 
focusing on single-species conservation. Establishing the environmental needs of a key component group of food webs, i.e. invertebrates, is therefore essential. Our results can be used in both infrastructure and conservation planning. And in a perfect world, the two should go hand in hand.

Acknowledgements MV and materials for the fieldwork were supported by a grant from the Maj and Tor Nessling Foundation. Special thanks to Meri Ensiö for helping with the invertebrate sampling and Stella Thompson for grammatical corrections.

Funding Information Open access funding provided by University of Helsinki including Helsinki University Central Hospital. MV and materials for the fieldwork were supported by a grant (201800264) from the Maj and Tor Nessling Foundation. The foundation did not have a role in the formulation of the study design, or in the collection, analyses, or interpretation of the data. They additionally did not influence the writing of the report, or the decision to submit our paper for publication.

\section{Compliance with ethical standards}

Conflict of interest The authors declare that they have no conflict of interest.

\section{Appendix}

Table 3 Characteristics of the study wetlands

\begin{tabular}{|c|c|c|c|c|}
\hline Wetland id & Area $(\mathrm{m} 2)$ & Isolation score & Isolation_type & Number of taxa \\
\hline 1 & 234 & 0.05 & Partly connected & 5 \\
\hline 2 & 767.4 & -0.27 & Partly connected & 4 \\
\hline 3 & 1880 & -0.21 & Partly connected & 8 \\
\hline 4 & 1040.8 & -0.12 & Partly connected & 7 \\
\hline 5 & 848 & 0.64 & Well-connected & 7 \\
\hline 6 & 623 & 0.37 & Partly connected & 7 \\
\hline 7 & 490 & 0.32 & Partly connected & 5 \\
\hline 8 & 2108 & 0.15 & Partly connected & 5 \\
\hline 9 & 376 & -0.87 & Isolated & 5 \\
\hline 10 & 2667.8 & 0.06 & Partly connected & 8 \\
\hline 11 & 619 & 2.18 & Well connected & 5 \\
\hline 12 & 1042 & -0.75 & Isolated & 6 \\
\hline 13 & 3034 & 0.50 & Well connected & 6 \\
\hline 14 & 340 & 0.28 & Partly connected & 10 \\
\hline 15 & 4400 & 0.15 & Partly connected & 4 \\
\hline 16 & 158 & -0.16 & Partly connected & 7 \\
\hline 17 & 1570.6 & 1.61 & Well connected & 11 \\
\hline 18 & 7889.6 & 1.63 & Well connected & 13 \\
\hline 19 & 296 & 1.94 & Well connected & 9 \\
\hline 20 & 56100 & -1.35 & Isolated & 7 \\
\hline 21 & 3118.9 & -0.59 & Isolated & 7 \\
\hline 22 & 113.7 & 0.16 & Partly connected & 5 \\
\hline 23 & 174.7 & 0.13 & Partly connected & 4 \\
\hline 24 & 723.3 & 1.78 & Well connected & 10 \\
\hline 25 & 3078 & -0.74 & Isolated & 7 \\
\hline 26 & 1251.8 & -2.12 & Isolated & 6 \\
\hline 27 & 929.5 & -0.21 & Partly connected & 8 \\
\hline 28 & 1316 & 0.30 & Partly connected & 6 \\
\hline 29 & 372 & -0.28 & Isolated & 0 \\
\hline 30 & 2040.4 & 0.16 & Partly connected & 5 \\
\hline 31 & 218 & 0.34 & Partly connected & 10 \\
\hline 32 & 623.9 & 2.53 & Well connected & 8 \\
\hline 33 & 843 & 0.86 & Well connected & 7 \\
\hline 34 & 608.3 & -1.08 & Isolated & 3 \\
\hline 35 & 1380.8 & 1.55 & Well connected & 10 \\
\hline 36 & 105 & -1.04 & Isolated & 3 \\
\hline 37 & 1441.6 & -0.61 & Isolated & 6 \\
\hline 38 & 1251.5 & 0.87 & Well connected & 6 \\
\hline 39 & 5271.5 & 0.07 & Partly connected & 6 \\
\hline 40 & 1240.4 & -2.20 & Isolated & 5 \\
\hline 41 & 572.9 & -1.21 & Isolated & 6 \\
\hline 42 & 1793 & -0.50 & Isolated & 9 \\
\hline
\end{tabular}


Table 3 (continued)

\begin{tabular}{lllll}
\hline Wetland id & Area $(\mathrm{m} 2)$ & Isolation score & Isolation_type & Number of taxa \\
\hline 43 & 2500 & -0.59 & Isolated & 5 \\
44 & 148034 & -0.67 & Isolated & 7 \\
45 & 422 & 0.06 & Partly connected & 6 \\
46 & 400 & -0.77 & Isolated & 4 \\
47 & 810 & 0.58 & Well connected & 8 \\
48 & 16870.6 & 0.28 & Partly connected & 4 \\
49 & 414 & -0.34 & Partly connected & 4 \\
50 & 11500 & -1.71 & Isolated & 2 \\
\hline
\end{tabular}

Open Access This article is licensed under a Creative Commons Attribution 4.0 International License, which permits use, sharing, adaptation, distribution and reproduction in any medium or format, as long as you give appropriate credit to the original author(s) and the source, provide a link to the Creative Commons licence, and indicate if changes were made. The images or other third party material in this article are included in the article's Creative Commons licence, unless indicated otherwise in a credit line to the material. If material is not included in the article's Creative Commons licence and your intended use is not permitted by statutory regulation or exceeds the permitted use, you will need to obtain permission directly from the copyright holder. To view a copy of this licence, visit http://creativecommons.org/licenses/by/4.0/.

\section{References}

Amezaga JM, Santamaria I, Green AJ (2002) Biotic wetland connectivity - supporting a new approach for wetland policy. Acta Oecol 23:213-222

Angel S, Parent J, Civco DL, Blei A, Potere D (2011) The dimensions of global urban expansion: Estimates and projections for all countries, 2000-2050. Prog Plann 75:53-107

Apinda Legnouo EA, Samways MJ, Simaika JP (2013) Value of artificial ponds for aquatic beetle and bug conservation in the Cape Floristic Region biodiversity hotspot. Aquatic Conservation Marine and Freshwater Ecosystems

Bates D, Maechler M (2009) lme4: linear mixed-effects models using S4 classes (Computer software manual). http://CRAN.R-project.org/ package $=1$ me 4

Becerra Jurado G, Masterson M, Harrington R, Kelly-Quinn M (2008) Evaluation of sampling methods for macroinvertebrate biodiversity estimation in heavily vegetated ponds. Hydrobiologia 597:97-107. https://doi.org/10.1007/s10750-007-9217-8

Bolker BM, Brooks ME, Clark CJ, Geange SW, Poulsen JR, Stevens MHS, White J-SS (2009) Generalized linear mixed models: a practical guide for ecology and evolution. Trends Ecol Evol 24(3):127135

Brönmark C, Klosiewski SP, Stein RA (1992) Indirect effects of predation in a freshwater, benthic food chain. Ecology 73:1662-1674

Clark NE, Lovell R, Wheeler BR, Higgins SL, Depledge MH, Norris K (2014) Biodiversity, cultural pathways, and human health: a framework. Trends Ecol Evol 29(4):198-204. https://doi.org/10.1016/j. tree.2014.01.009

Colburn EA (2008) Vernal pools: Natural history and conservation, 2nd edn. The McDonald \& Woodward Publishing Company, Blacksburg, Virginia and Grandville, Ohio

Costanza R, de Groot R, Sutton PC, Van der Ploeg S, Anderson S, Kubiszewski I, Farber S, Turner RK (2014) Changes in the Global value of ecosystem services. Glob Environ Change 26:152-158
Covich AP, Palmer MA, Crowl TA (1999) The role of benthic invertebrate species in freshwater ecosystem: Zoobenthic species influence energy flows and nutrient cycling. Bioscience 49:119-127

Davidson N (2014) How much wetland has the world lost? Long-term and recent trends in global wetland area. Marine Freshwater Research 65:934-942

Davies ZG, Fuller RA, Loram A, Irvine KA, Sims V, Gaston KJ (2009) A national scale inventory of resource provision for biodiversity within domestic gardens. Biol Cons 142(4):761-771

Davies SR, Sayer CD, Greaves H, Siriwardena GM, Axmacher JC (2016) A new role for pond management in farmland bird conservation. Agriculture Ecosystems Environment 233:179-191

Dhindsa MS, Sandhu PS, Toor HS (1988) Roadside birds in Punjab (India): relation to mortality from vehicles. Environ Conserv 15: 303-310

Downing AL, Leibold MA (2002) Ecosystem consequences of species richness and composition in pond food webs. Nature 416:837-841

Dudgeon D, Athington AH, Gessner MO, Kawabata Z, Knowler DJ, Levequ C, ... Sullivan CA (2006) Freshwater biodiversity: Importance, threats, status and conservation challenges. Biol Rev 81:163-182

Elmberg J, Nummi P, Pöysä H, Sjöberg K (1992) Do intruding predators and trap position affect the reliability of catches in activity traps? Hydrobiologia 239:187-193

Emerton L, Bos E (2004) Value. Counting ecosystems as an economic part of water infrastructure (Report). IUCN. Gland, Switzerland and Cambridge, UK. Available from cmsdata.iucn.org/downloads/ value en.pdf

Eriksson MOG (1976) Food and feeding habits of downy goldeneye (Bucephala clangula) (L.) ducklings. Ornis Scandinavica 7:159-169

ESRI (2015) Redlands. Environmental Systems Research Institute Inc, CA

Euliss NH Jr, Mushet DM, Wrubleski DA (1999) Invertebrates in freshwater wetlands of North America: Ecology and Management. In: Batzer DP, Rader RB, Wissinger SA (eds) Invertebrates in Freshwater Wetlands of North America: Ecology and Management. John Wiley and Sons Inc., New York, pp 471-514

European Union (2016) Urban Europe: Statistics on cities, towns and suburbs. Statictical Books. Luxembourg: Publications office of the European Union. https://doi.org/10.2785/91120

Finlayson CM, D'Cruz R (2005) Inland Water Systems. In: Hassan R, Scholes R, Ash N (eds) Ecosystems and Human Well-being: Current State and Trends Millennium Ecosystem Assessment Board. Island Press, Washington, D.C., pp 553-583 (Retrieved from document.356.aspx.pdf)

Finnish Environmental Institute (2014) CLC2012 Finland. Finnish Environmental Institute, Helsinki

Finnish Traffic Agency (2018) Digiroad 2018. Finnish Traffic Agency, Helsinki

Foltz S, Dodson S (2009) Aquatic Hemiptera community structure in stormwater retention ponds: a watershed land cover approach. Hydrobiologia 621:49-62 
Fontanarrosa MS, Collantes MB, Bachmann A (2013) Aquatic insect assemblages of man-made permanent ponds, Buenos Aires City, Argentina. Neotrop Entomol 42:22-31

Franklin JF (1993) Preserving biodiversity: species, ecosystems, or landscapes? Ecol Appl 3:202-205

Garcia EA, Mittelbach GG (2008) Regional coexistence and local dominance in Chaoborus: species sorting along a predation gradient. Ecology 89:1703-1713

Gaston KJ, Smith RM, Thompson K, Warren PH (2005) Urban domestic gardens (II): experimental tests of methods for increasing biodiversity. Biodivers Conserv 14:395-413

Gaston KJ, Rodrigues ASL, van Rensburg BJ, Koleff P, Chown SL (2001) Complementary representation and zones of ecological transition. Ecol Lett 4:4-9

Gauch HG Jr (1982) Multivariate analysis in community ecology. Cambridge (Cambridge university Press), pp. 298

Gledhill DG, James P, Davies DH (2008) Pond density as a determinant of aquatic species richness in an urban landscape. Landscape Ecol 23:1219-1230

Hanski I (1999) Metapopulation ecology. Oxford University Press, New York

Hassall C (2014) The ecology and biodiversity of urban ponds. Wiley Interdiscip Rev 1:187-206

Hassall C, Anderson S (2015) Stormwater ponds can contain comparable biodiversity to unmanaged wetlands in urban areas. Hydrobiologia 745:137-149

Hassall C, Hill MJ, Gledhill D, Biggs J (2016) The ecology and management of urban pondscapes. In: Francis RA, Millington J, Chadwick MA (eds) Urban landscape ecology: Science, policy and practice. Routledge, London, pp 129-147

Heino J (2014) Taxonomic surrogacy; numerical resolution and responses of stream macroinvertebrate communities to ecological gradients: are the inferences transferable among regions? Ecologial Indicators 36:186-194

Heino J, Bini LM, Andersson J, Bergsten J, Bjelke U, Johansson F (2017) Unravelling the correlates of species richness and ecological uniqueness in a metacommunity of urban pond insects. Ecol Indic 73:422-431

Hill MJ, Hassall C, Oertli B et al (2018) New policy directions for global pond conservation. Conservation Letters 11:e12447. https://doi.org/ $10.1111 /$ conl.12447

Hill MJ, Ryves DB, White JC, Wood PJ (2016) Macroinvertebrate diversity in urban and rural ponds: Implications for freshwater biodiversity conservation. Biol Cons 201:50-59

Hill MJ, Mathers KL, Wood PJ (2015) The aquatic macroinvertebrate biodiversity of urban ponds in a medium sized European town (Loughborough, UK). Hydrobiologia 760:225-238

Hill MJ, Wood PJ (2014) The macroinvertebrate biodiversity and conservation value of garden and field ponds along a rural - urban gradient. Fundam Appl Limnol 185:107-119

Jones JI, Sayer CD (2003) Does the fish-invertebrate periphyton cascade precipitate plant loss in shallow lakes? Ecology 84:2155-2167

Keddy PA (2000) Wetland Ecology: Principles and Conservation. Cambridge University Press, Cambridge

Koleff P, Gaston KJ, Lennon JJ (2003) Measuring beta diversity for presence-absence data. J Anim Ecol 72:367-382

Martin TH, Crowder LB, Dumas CF, Burkholder JM (1992) Indirect effects of fish on macrophytes in Bays Mountain Lake: evidence for a littoral trophic cascade. Oecologia 89:476-481

Martínez-Sanz C, Canzano CSS, Fernández-Aláez M, García-Criado F (2012) Relative contribution of small mountain ponds to regional richness of littoral macroinvertebrates and the implications for conservation. Aquatic Conservation: Marine Freshwater Ecosystem 22: $155-164$

McCauley SJ, Davis CJ, Relyea RA, Yurewicz KL, Skelly DK, Werner EE (2008) Metacommunity patterns in larval odonates. Oecologia $158: 329-342$
McDonald RI, Kareiva P, Forman RTT (2008) The implications of current and future urbanization for global protected areas and biodiversity conservation. Biol Conserv 141:1695-1703

McKinney ML (2008) Effects of urbanization on species richness: a review of plants and animals. Urban Ecosystems 11:161-176

MEA: Millennium Ecosystem Assessment (2005) Ecosystems and Human Well-being: Synthesis. Report. Island Press, Washington, DC, USA

Merrill RJ, Johnson DM (1984) Dietary niche overlap and mutual predation among coexisting larval Anisoptera. Odonatologica 13:387-406

Mitsch WJ, Gosselink JG (2007) Wetlands, 4th edn. John Wiley \& Sons Inc., Hoboken

Moore AA, Palmer MA (2005) Invertebrate biodiversity in agricultural and urban headwater streams: Implications for conservation and management. Ecol Appl 15:1169-1177

Nichols E, Peres CA, Hawes JE, Naeem S (2016) Multitrophic diversity effects of network degradation. Ecology Evolution 6(14):4936-4946

Oertli B, Joye DA, Castella E, Juge R, Cambin D, Lachavanne JB (2002) Does size matter? The relationship between pond area and biodiversity. Biol Cons 104:59-70

Oertli B, Parris KM (2019) Review: Toward management of urban ponds for freshwater biodiversity. Ecosphere 10(7):e02810. https://doi.org/ $10.1002 /$ ecs 2.2810

Paul MJ, Meyer JL (2001) Streams in the urban landscape. Annu Rev Ecol Syst 32:333-365

Pimental RA (1979) Morphometrics. The multivariate analysis of biological data. Dubuque (Kendall/Hunt Publishing Company), pp. 276

R Development Core Team (2013) R: A Language and Environment for Statistical Computing. R Foundation for Statistical Computing. Vienna Austria. The R Foundation for Statistical Computing. ISBN: 3-90005107-0. [Available online at <http://www.R-project.org/>.]

Relyea RA (2002) Local population differences in phenotypic plasticity: predator-induced changes in wood frog tadpoles. Ecol Monogr 72: 77-93

Russi D, ten Brink P, Farmer A, Badura T, Coates D, Förster J, Kumar R, Davidson N (2013) The Economics of Ecosystems and Biodiversity for Water and Wetlands. IEEP, London and Brussels; Ramsar Secretariat, Gland

Sabo JL, Soykan CU (2006) Riparian zones increase regional richness by supporting different, not more, species: reply. Ecology 87(8):21282131

Seibert HC, Conover JH (1991) Mortality of vertebrates and invertebrates on an Athens County, Ohio, highway. Ohio Journal of Science 91: $163-166$

Seto KC, Fragkias M, Güneralp B, Reilly MK (2011) A meta-analysis of global urban land expansion. PLoS ONE 6:e23777

Seto KC, Güneralp B, Hutyra LR (2012) Global forecasts of urban expansion to 2030 and direct impacts on biodiversity and carbon pools. PNAS 109(40):16083-16088

Schneider FD, Brose U, Rall BC, Guill C (2016) Animal diversity and ecosystem functioning in dynamic food webs. Nature Communication 7:12718

Schneider A, Friedl MA, Potere D (2010) Mapping global urban areas using MODIS 500-m da datasets based on 'urban ecoregions.' Remote Sensing of Environment 114:1733-1746

Skelly DK, Freidenburg LK, Kiesecker JM (2002) Forest canopy and the performance of larval amphibians. Ecology 83:983-992

Solecki W, Seto KC, Marcotullio PJ (2013) It's time for an urbanization science. Environment 55:12-17

Stewart RI, Andersson GK, Brönmark C, Klatt BK, Hansson LA, Zülsdorff V, Smith HG (2017) Ecosystem services across the aquatic-terrestrial boundary: Linking ponds to pollination. Basic Appl Ecol 18:13-20

Sugden LG (1973) Feeding ecology on portail, gadwall, American widgeon and lesser scaup ducklings in southern Alberta. Canadian Wildlife Service Report Series 24:1-47 
Takamura N (2012) Status of biodiversity loss in lakes and ponds in Japan. In: Nakano S, Yahara T, Nakashizuka T (eds) The biodiversity observation network in the Asia-Pacific region: Towards further development of monitoring, 148. Springer, Tokyo, p 133

The Pond Manifesto EPCN (2008) The Pond Manifesto: 1-20. Retrieved from https://freshwaterhabitats.org.uk/wp-content/uploads/2016/06/ EPCN-MANIFESTO.pdf

Thébault E, Loreau M (2003) Food-web constraints on biodiversityecosystem functioning relationships. Proc Natl Acad Sci USA 100(25):14949-14954

Trombulak SC, Frissell CA (2000) Review of ecological effects of roads on terrestrial and aquatic communities. Conserv Biol 14(1):18-30

Turner MG, Gardner RH, O’Neill RV (2003) Landscape ecology in theory and practice. Springer, New York

Urban MC (2004) Disturbance heterogeneity determines freshwater metacommunity structure. Ecology 85:2971-2978

Venables WN, Ripley BD (2002) Modern Applied Statistics with S, 4th edn. Springer, New York. ISBN 0-387-95457-0

Verdonschot PFM, Besse-Lototskaya AA (2014) A flight distance of mosquitoes (Culicidae): A metadata analysis to support the management of barrier zones around rewetted and newly constructed wetlands. Limnologica 45:69-79

Vörösmarty CJ, McIntyre PB, Gessner MO, Dudgeon D, Prusevich A, Green P, Glidden S, Bunn SE, Sullivan CA, Reidy Liermann C,
Davies PM (2010) Global threats to human water security and river biodiversity. Nature 467:555

Wellborn GA, Skelly DK, Werner EE (1996) Mechanisms creating community structure across a freshwater habitat gradient. Annu Rev Ecol Syst 27:337-363

Werner EE, Glennemeier KS (1999) Influence of forest canopy cover on the breeding pond distributions of several amphibian species. Copeia 1999: 1-12

Wissinger SA (1999) Ecology of Wetland Invertebrates - Synthesis and Applications for conservation and Management. In: Batzer DP, Rader RB, Wissinger SA (eds) Invertebrates in Freshwater Wetlands of North America: Ecology and Management. John Wiley and Sons Inc., New York, pp 1043-1086

Wood SN (2004) Stable and efficient multiple smoothing parameter estimation for generalized additive models. J Am Stat Assoc 99:673686

Wood PJ, Greenwood MT, Barker SA, Gunn J (2001) The effects of amenity management for angling on the conservation value of aquatic invertebrate communities in old industrial mill ponds. Biol Conserv 102:17-29

Woodward R, Wui Y-S (2001) The economic value of wetland services: a meta-analysis. Ecol Econ 37(2):257-270

Zuur AF, Ieno EN, Walker NJ, Saveliev AA, Smith GM (2009) Mixed Effects Models and Extension in Ecology with R. Springer Science + Business Media, New York 